\title{
The Turkish Language and Psychometric Validation of the "Bladder Control Self-assessment Questionnaire" Evaluating the Lower Urinary Tract Dysfunction
}

\author{
Alt Üriner Sistem Disfonksiyonunu Değerlendiren "Bladder Control Self-assessment \\ Questionnaire" in Türkçe Dil ve Psikometrik Validasyonu
}

\author{
(D) Mustafa Bilal Hamarat1, (D) Fatih Tarhan², (D) Utku Can², (D) Erkin Sağlam³, (D) Pınar Ay4 \\ 1 University of Health Sciences Turkiye, Konya Training and Research Hospital, Clinic of Urology, Konya, Turkiye \\ 2University of Health Sciences Turkiye, Kartal Dr. Lütfi Kırdar Training and Research Hospital, Clinic of Urology, Istanbul, Turkiye \\ 3SRH Sigmaringen Hospital, Clinic of Urology, Berlin, Germany \\ 4Marmara University Faculty of Medicine, Department of Public Health, Istanbul, Turkiye
}

What's known on the subject? and What does the study add?

B-SAQ has not yet been validated in Turkish. The aim of this study was to develop and validate the Turkish version of the B-SAO.

\begin{abstract}
Objective: The aim of this study was to develop and validate the Turkish version of the Bladder Control Self-assessment Questionnaire (B-SA0). Materials and Methods: B-SAQ that comprises two parts and four questions in each section was translated into Turkish, followed by a backtranslation into English. The study included 79 and 49 women who were admitted to the urology outpatient clinic with and without complaints of lower urinary tract symptom (LUTS), respectively. Turkish B-SAQ questionnaire was filled for the second time by 67 patients after a two week interval for test-retest correlation. All patients filled the Turkish B-SAQ form, "International Consultation on Incontinence Questionnaire Short Form" (ICIQ$\mathrm{SF}$ ) and "Overactive Bladder Screener" (OAB-V8) questionnaire.

Results: The Cronbach alpha value for B-SAO was 0.868. Reliability of the test/retest was found to be $0.860(p<0.001)$. There were statistically significant differences in B-SAQ scores between the controls and patients $(p<0.001)$. Convergent validity analyzes with ICIQ-SF and $0 A B-V 8$ (respectively $r=0.61$ and $r=0.44, p<0.001$ ). The total $B-S A Q$ cut-off score was determined as 7 . The sensitivity and specificity of B-SAQ were $96 \%$ in women with LUTS.

Conclusion: Turkish version of B-SAQ is a valid and reliable questionnaire to evaluate the symptoms and disorders of patients with LUTS. Keywords: Lower urinary tract symptoms, Validation, B-SAO
\end{abstract}

Öz

Amaç: Bu çalışmada "Bladder Control Self-assessment Questionnaire" (B-SAO) Türkçe versiyonunun geliştirilmesi ve valide edilmesi amaçlandı.

Gereç ve Yöntem: İki bölüm ve her bölümde dört sorudan oluşan B-SAO Türkçe'ye çevrildi ve daha sonra tekrar İngilizce'ye çevrildi. Üroloji polikliniğimize alt üriner sistem yakınmaları ile başvuran 79 kadın hasta ve herhangi bir alt üriner sistem şikayeti olmayan 49 kadın hasta çalışmaya dahil edildi. Test-retest uyumluluğu için, ayrıca 67 hastaya iki hafta ara ile Türkçe B-SAO sorgulama formu ikinci kez doldurtuldu. Tüm hastalara Türkçe B-SAQ, "International Consultation on Incontinence Questionnaire Short Form" (ICIQ-SF) ve "Overactive Bladder Screener" (OAB-V8) formları doldurtuldu.

Bulgular: B-SAQ için Cronbach alfa değeri 0,868 idi. Test/retest güvenilirliği 0,860 ( $<<0,001)$ olarak bulundu. Kontrol ve hasta grupları arasında B-SAO skorları açısından istatistiksel anlamlı farklılık bulundu $(p<0,001)$. ICIQ-SF ve OABO ile convergant geçerlilik analizleri yapıldı (sırasıyla

Correspondence: Mustafa Bilal Hamarat MD, University of Health Sciences Turkiye, Konya Training and Research Hospital, Clinic of Urology, Konya, Turkiye Phone: +90 5336593586 E-mail: bilalhamarat@gmail.com ORCID-ID: orcid.org/0000-0002-3987-7016

Received: $30.01 .2020 \quad$ Accepted: 09.05.2020

Cite this article as: Hamarat MB, Tarhan F, Can U, Sağlam E, Ay P. The Turkish Language and Psychometric Validation of the "Bladder Control Self-assessment Questionnaire" Evaluating the Lower Urinary Tract Dysfunction. J Urol Surg 2020;7(4):285-289.

๑Copyright 2020 by the Association of Urological Surgery / Journal of Urological Surgery published by Galenos Publishing House. 
$r=0,61$ ve $r=0,44, p<0,001)$. B-SAQ için toplam eşik değer 7 puan olarak belirlenmiştir. Alt üriner sistem semptomları olan kadın hastalarda hastalığı tanımlamadaki sensitivite ve spesifitesi \%96 olarak bulundu.

Sonuç: B-SAQ'nun Türkçe versiyonu, alt üriner sistem semptomlu hastaların semptomlarını ve rahatsızlıklarını değerlendiren geçerli ve güvenilir bir sorgulama formudur.

Anahtar Kelimeler: Alt üriner sistem semptomları, Validasyon, BSAO

\section{Introduction}

Lower urinary tract symptoms (LUTS) include voiding (slow stream, splitting or spraying, intermittency, hesitancy, straining to void and terminal dribble), storage (urgency, frequency, urinary incontinence and nocturia), and post-mictional (feeling of incomplete emptying and post micturition dribble) symptoms (1). The incidence and severity of LUTS increases with age and negatively affects the quality of life $(1,2)$. The popular belief that LUTS are a natural consequence of life can prevent patients from seeking help in this regard. Storage symptoms of the lower urinary tract consist of complaints of urgent urination sensation and/or urgent urination, incontinence, frequent urination, and nocturnal urination (nocturia) (3). The quality of life of the patients with LUTS that is especially accompanied by urinary incontinence is highly negatively affected. In communitybased studies, the prevalence of patients with at least one of the LUTS varied from $64.3 \%$ to $74.4 \%$. The incidence of storage symptoms was observed to be higher in women than in men, and it increased with older age $(4,5)$. A prevalence study of 2730 men over 40 years of age from 19 different provinces in Turkey reported that 3 out of 4 men aged $\geq 40$ years exhibited some degree of LUTS (6).

Although, LUTS is a clinical problem that is frequently encountered in urology practice, it can easily be overlooked if the patient's complaints are not properly questioned. Particularly, patients in our country do not express their complaints on this issue unless questioned. In one study, it was predicted that people with LUTS will wait for an average of 4 years before asking for help (7). It was observed that women seek medical assistance for uncomfortable LUTS lesser than men (8). Questionnaires are needed to diagnose such patients and to monitor their response to treatment. The severity of the complaints should be clearly revealed by the questionnaire forms and the questions should be clear.

Bladder Control Self-assessment Questionnaire (B-SAQ), developed by an expert panel on LUTS, comprises eight items that determine LUTS and related disorders (9). Our study aimed to determine the validity and reliability of the Turkish version of B-SAO.

\section{Materials and Methods}

The study included 79 and 49 women who were admitted to the urology outpatient clinic with and without complaints of LUTS, between February 2016 and June 2016, respectively. Sixty-seven women reported for evaluating the test-retest compliance. Patients with history of trauma, diabetes mellitus, neurogenic lower urinary tract dysfunction, pelvic surgery, cancer, and radiotherapy; and those with active urinary tract infection and those who used medications affecting the lower urinary tract, were excluded from the study. Additionally, patients who were illiterate or had mental problems and could not give consent, were excluded from the study. Our study was approved by the Ethics Committee (08/04/2014-13) of our institution and informed written consent was obtained from all patients before participating in the study.

The validation of the B-SAQ, comprising two parts as symptoms and disorders and with four questions in each part, was carried out in a gradual manner by the method suggested by Hutchinson et al. (10). Firstly, it was translated from English to Turkish by two independent Turkish translators who were not familiar with the B-SAQ, followed by a meeting of the research group with the translators to evaluate the Turkish versions of $\mathrm{B}-\mathrm{SAQ}$, and first consensus was reached for the Turkish version. The consensual Turkish form was translated into English by another two translators who were not familiar with the original questionnaire. A second consensus meeting was held in which the original and back-translated versions were evaluated and the final version of the B-SAO was obtained as a result of the necessary corrections performed by the established committee. Finally, in a pilot study on 10 women, it was found that the $\mathrm{B}-\mathrm{SAO}$ was easily implemented in a short time and no further changes were made in the last Turkish version of the B-SAO.

In this questionnaire, patients' total scores ranging from 0 to 12 for each part were obtained with a scale ranging from 0 to 3 points for each question.

All patients filled in the Turkish B-SAQ form (Appendix 1), "International Consultation on Incontinence Questionnaire Short Form" (IClQ-SF), and "Overactive Bladder Screener" (OAB-V8) (11) questionnaire. After two weeks, the test-retest compatibility group was asked to fill the Turkish B-SAO questionnaire again. Three-day voiding diary, complete urine analysis, urine culture, blood creatinine measurement, urinary 
tract ultrasonography, direct urinary tract X-ray examinations, and physical examinations were performed for all patients.

\section{Statistical Analysis}

The characteristics of the study group and controls were analyzed using descriptive statistics. Psychometric analyses of the B-SAO were performed by the following procedures. Reliability was evaluated by test-retest reliability and internal consistency. Cronbach's $\alpha$ coefficient was used to test the internal consistency of the Turkish B-SAO. Test-retest reliability was also evaluated with Spearman correlation. B-SAO scores of patients were compared between two visits (test-retest) by using Wilcoxon signed-rank test. The correlation between Turkish versions of $\mathrm{B}-\mathrm{SAQ}, \mathrm{OAB}-\mathrm{V} 8$, and ICIQ-SF questionnaires were evaluated by Spearmen correlation coefficient to determine the convergent validity. Discriminant validity was assessed by comparing the B-SAQ scores of patients with those of controls. The MannWhitney $U$ test was used to explore the mean differences between the controls and patients. The experts assessed the content validity that indicated whether the questionnaire made sense to the patients and experts and whether the items covered all important aspects or if there were any missing components. Receiver operating characteristic (ROC) plots were used to define the detection cut-off or threshold score that best reflected optimal sensitivity and specificity. The data analyses were conducted using SPSS version 22.0 (IBM, USA) and were twosided with $\mathrm{p}<0.05$ defined as statistically significant.

\section{Results}

The study included 79 women with LUTS and 49 healthy women controls with mean ages of 40.3 and 42.1 years, respectively. There were no significant differences between the groups $(p=0.42)$. Demographic data of the patients included in the study and the results of the questionnaires are given in Table 1. A statistical difference between the study and control groups was detected for all questions $(p<0.05)$ (Table 1$)$.

The Cronbach alpha values for Turkish B-SAO total, B-SAQsymptom, and B-SAQ-bother were $0.868,0.753$, and 0.749 respectively. Individual items in the B-SAO scored values of 0.835-0.870, reflecting high levels of internal consistency. Testretest reliability was performed on 67 LUTS patients. A high correlation was observed between test-retest scores $(r=0.860$, $p<0.01)$. B-SAQ symptom, bother, and total test-retest scores did not show a significant difference $(p>0.05)$ (Table 2). The domains of the Turkish B-SAO correlated well with each other according to the Spearman correlation test and showed a high correlation with ICIQ-SF and OAB-V8 $(r=0.61, p=0.01$; $r=0.44, p=0.01$; respectively). All other correlation scores were significant at the 0.01 level (Table 3).
The ROC curve for the B-SAO Turkish version is given in Figure 1. When total B-SAO score of 7 score was used as the predictive value, the sensitivity and specificity of B-SAQ were calculated as $96 \%$ and $96 \%$ in patients with LUTS symptoms,

Table 1. Basic characteristics: Age, B-SAO, ICIO-SF, OAB-V8 scores in study groups

\begin{tabular}{|l|l|l|l|}
\hline & LUTS & Control & $\mathbf{p}^{*}$ \\
\hline Number of patients & 79 & 49 & \\
\hline Age (year) & $\begin{array}{l}40.3 \pm 15.5 \\
(24-62)\end{array}$ & $\begin{array}{l}42.1 \pm 15.6 \\
(25-64)\end{array}$ & 0.420 \\
\hline B-SA0 score Symptom & $9.2 \pm 2.7$ & $0.8 \pm 1.0$ & $<0.001$ \\
\hline Bother & $9.6 \pm 2.5$ & $0.7 \pm 1.1$ & $<0.001$ \\
\hline Total & $18.8 \pm 4.9$ & $1.5 \pm 2.1$ & $<0.001$ \\
\hline ICIQ-SF & $14.0 \pm 5.0$ & 0 & $<0.001$ \\
\hline OAB-V8 & $22.8 \pm 9.1$ & $3.1 \pm 2.4$ & $<0.001$ \\
\hline $\begin{array}{l}{ }^{*} \text { Mann-Whitney U test. B-SAQ: Bladder control self-assessment questionnaire, ICIQ- } \\
\text { SF: International consultation on incontinence questionnaire short form, OAB-V8: } \\
\text { Overactive bladder screener, LUTS: Lower urinary tract symptom }\end{array}$ \\
\hline
\end{tabular}

Table 2. Internal consistency of the study (Cronbach's alpha coefficient)* and test-retests (Spearman)**

\begin{tabular}{|l|l|l|l|l|}
\hline & $\begin{array}{l}\text { Cronbach's } \\
\text { alpha } \\
(\mathbf{n = 1 2 8})\end{array}$ & \multicolumn{2}{|l|}{ Test-retest $(\mathbf{n = 6 7 )}$} & \\
\cline { 2 - 5 } & $\mathbf{p}^{*}$ & $\begin{array}{l}\text { Test } \\
\text { Mean }\end{array}$ & $\begin{array}{l}\text { Retest } \\
\text { Mean }\end{array}$ & $\mathbf{p}^{* *}$ \\
\hline B-SAQ-total & 0.868 & $18.8 \pm 5.0$ & $18.3 \pm 4.1$ & 0.860 \\
\hline B-SAQ-symptom & 0.713 & $8.9 \pm 2.7$ & $9.0 \pm 2.3$ & 0.764 \\
\hline B-SAQ-bother & 0.738 & $9.9 \pm 2.6$ & $9.3 \pm 2.2$ & 0.846 \\
\hline
\end{tabular}

${ }^{*}$ Cronbach's alpha, **Wilcoxon Signed Ranks test, B-SAQ: Bladder control selfassessment questionnaine

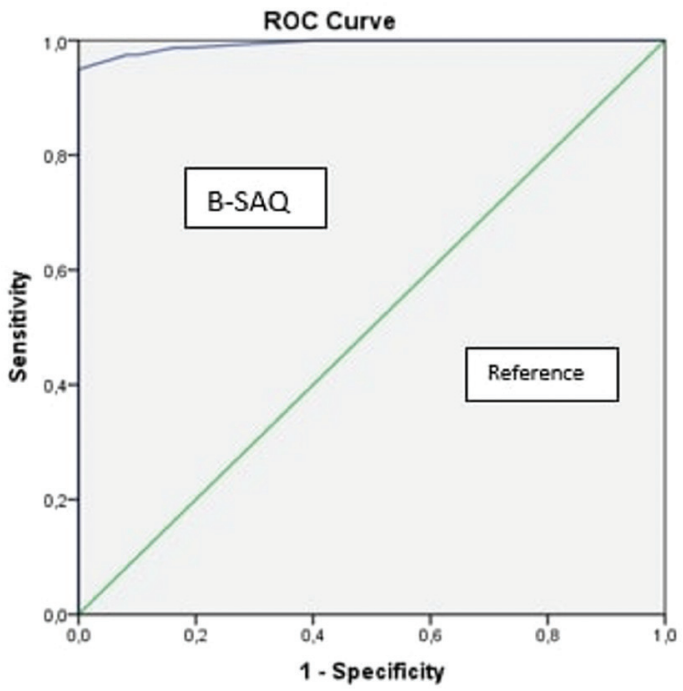

Figure 1. Area under the ROC curve for BSAO Turkish versions

ROC: Receiver operating characteristic, BSAO: Bladder control selfassessment questionnaire 


\begin{tabular}{|l|l|l|l|l|l|}
\hline \multicolumn{6}{|l|}{$\begin{array}{l}\text { Table 3. Correlations (Spearman) of B-SAQ-symptom and } \\
\text { bother score, ICIQ-SF (questions } 3+4+5 \text { ) and OAB-V8 } \\
\text { among } 79 \text { patients with overactive bladder symptoms } \\
\text { a-SAQ- }\end{array}$} \\
\begin{tabular}{l|l|l|l|l|} 
B-SAQ- \\
symptom \\
total
\end{tabular} & $\begin{array}{l}\text { B-SAQ- } \\
\text { bother }\end{array}$ & $\begin{array}{l}\text { ICIQ- } \\
\text { SF }\end{array}$ & OAB-V8 \\
\hline B-SAQ-Total & 1 & & & & \\
\hline $\begin{array}{l}\text { B-SAQ- } \\
\text { symptom }\end{array}$ & $0.95^{*}$ & 1 & & & \\
\hline B-SAQ-bother & $0.92^{*}$ & $0.77^{*}$ & 1 & & \\
\hline ICIQ-SF & $0.61^{*}$ & $0.61^{*}$ & $0.56^{*}$ & 1 & \\
\hline OAB-V8 & $0.44^{*}$ & $0.5^{*}$ & $0.34^{*}$ & $0.39^{*}$ & 1 \\
\hline
\end{tabular}

${ }^{*}$ Correlation is significant at the 0.01 level, B-SAQ: Bladder control self-assessment questionnaine, ICIQ-SF: International consultation on incontinence questionnaire short form, OAB-V8: Overactive bladder screener

respectively, and the area beneath the ROC curve was $0.994 \pm 0.005(p<0.001)$. A symptom score threshold of 4 showed that the B-SAO had a sensitivity and specificity of $95 \%$ and $96 \%$ for the detection of LUTS, respectively. For a bother score threshold of 4, the sensitivity and specificity were 98 and $96 \%$, respectively. Here, ROC curves showed high accuracy of B-SAO, represented by the large area below curve 0.994 that identified patients with LUTS.

\section{Discussion}

Although, LUTS is a common clinical condition in our country, there are limited questionnaires pertaining to it that have been translated into Turkish and validated. One of them, ICIQ-SF form, was first translated into Turkish and validated by Çetinel et al. (12) in 2004. In this study, we aimed to validate the Turkish version of $\mathrm{B}-\mathrm{SAQ}$, a questionnaire that can be filled in a very short time by a majority of patients. The B-SAQ form is a short and easy-to-understand questionnaire developed by Basra et al. (9) in 2006 to determine LUTS.

In 2014, Sahai et al. (13) performed the validation study of the B-SAQ form in men with LUTS and showed it to have a good correlation with the Kings Health Questionnaire (KHO). In the same study, B-SAQ was shown to be less specific in men than in women, and $98 \%$ of patients were observed to fill the form in less than 5 minutes. In the study of Cidre et al. (14), 3-day voiding diary and B-SAO to evaluate patients with overactive bladder were reported to be the tests with the best diagnostic performance.

The Cronbach's alpha value that shows the internal consistency for the B-SAO test was 0.91 in the study conducted by Basra et al. (9), while it was 0.87 in our study. A correlation between test-retest scores was presented. The reliability of the test was thus established to be quite high.

The total score of B-SAQ and the symptom and discomfort scores individually were observed to show correlation with ICIQ-SF and
OAB-V8 scores in the patient group. In the study by Basra et al. (9), symptom scores of the B-SAQ correlated highly with that of the KHO (Pearson's correlation values of 0.46-0.54). In our study, symptom scores of the B-SAQ correlated highly with that of the ICIQ-SF (questions $3+4+5$ ) (Spearman correlation value: 0.61 ). In our study and the one by Sahai et al. (13), B-SAO symptom and discomfort scores correlated well (Spearman $r=0.77$, $p<0.01$; Pearson's $r=0.94, p<0.01$; respectively). Espuña et al. (15), reported the Spearman's correlation coefficient between "discomfort" scale and the ICIQ-SF (question $3+4+5$ ) as 0.65 $(p<0.001)$, and in our study, this coefficient was $0.56(p<0.001)$. The total B-SAO score correlated moderately with the OAB-V8 score, while it showed a high correlation with ICIQ-SF (Table 3).

While, Espuña et al. (15) in their Spanish validation study of B-SAQ had considered point 6 as the cut-off point for B-SAQ subscales, we considered point 7 as the cut-off point in the ROC curve. When B-SAO score of 7 was used as the predictive value, the sensitivity and specificity of B-SAQ in patients with LUTS was found to be $96 \%$ and $96 \%$, respectively. In the study of Sahai et al. (13), a symptom score threshold of 4 showed that the B-SAO had the sensitivity and specificity of 75\% and $87 \%$ for the detection of LUTS, respectively. When the same threshold was taken as a reference in our study, B-SAQ had the sensitivity and specificity of 95\% and 96\% for the detection of LUTS, respectively. Higher sensitivity and specificity in our study was due to the fact that the study was performed only in women. This showed that the sensitivity and specificity of $\mathrm{B}-\mathrm{SAO}$ are higher in women than in men for the detection of LUTS. In a study comparing the questionnaires conducted by Angulo et al. (16) in 2007 on Spanish community, the area under the curve (AUC) for B-SAQ was 0.799; in another study of Basra et al. (17), it was 0.83; in the study by Sahai et al. (13), it was 0.88; while in our study, this area was $0.994(16,17)$. The high AUC value in our study showed the high accuracy of B-SAO in patients with LUTS.

Two patients who noted their hematuria complaint with a warning statement under the B-SAO form were examined in this respect. Renal calculus was detected in one patient. Therefore, it was thought that this warning statement also added significant value to the test due to enabling the detection of other underlying urological diseases.

\section{Study Limitations}

There are some limitations in this study. Firstly, we did not compare B-SAO questionnaire with a female LUTS survey such as the Bristol LUTS questionnaire. Another limitation was that the design of the B-SAO was changed due to the poor understanding of text by our patients during translation phase of the study. 


\section{Conclusion}

The obtained Turkish version of B-SAO questionnaire whose validity and reliability related to overactive bladder disease has been shown previously, can be filled in a short time, is easy to apply, and was proven to be a valid and reliable test for Turkish population. Thus, it will be possible to use one more questionnaire pertaining to the lower urinary system, for which a validation study has not been previously conducted, in clinical practice in our country.

\section{Ethics}

Ethics Committee Approval: Ethics committee approval was received for this study from the Kartal Dr. Lütfi Kırdar Training and Research Hospital Scientific Research Evaluation Board (approval no: 89513307/1009/278, date: 08.04.2014)

Informed Consent: Informed written consent was obtained from all patients before participating in the study.

\section{Author Contributions}

Concept: M.B.H., F.T., E.S., Design: M.B.H., F.T., U.C., E.S., P.A., Supervision: M.B.H., F.T., U.C., Resources: F.T., P.A., Materials: M.B.H., U.C., E.S., Data Collection and/or Processing: M.B.H., U.C., E.S., Analysis and/or Interpretation: M.B.H., F.T., P.A., Literature Search: M.B.H., U.C., Writing: M.B.H., F.T., U.C., Critical Review: M.B.H., F.T., E.S., P.A.

Conflict of Interest: The authors have no conflicts of interest to declare.

Financial Disclosure: The authors declared that this study has received no financial support.

\section{References}

1. Abrams $P$, Cardozo L, Fall M, Griffiths $D$, Rosier $P$, Ulmsten U, van Kerrebroeck P, Victor A, Wein A, Standardisation Sub-committee of the International Continence Society. The standardisation of terminology of lower urinary tract function: report from the Standardisation Sub-committee of the International Continence Society. Neurourol Urodyn 2002;21:167-178.

2. Abrams $P$. The urodynamic assessment of lower urinary tract symptoms. Proceedings of the Fifth International Consultation on Benign Prostatic Hyperplasia (BPH), Paris, June 2000, 2001.

3. Abrams $P$, Cardozo L, Fall M, Griffiths D, Rosier P, Ulmsten U, van Kerrebroeck $P$, Victor A, Wein A. The standardisation of terminology of lower urinary tract function: report from the Standardisation Sub-committee of the International Continence Society. Am J Obstet Gynecol 2002;187:116-126.
4. Irwin DE, Milsom I, Hunskaar S, Reilly K, Kopp Z, Herschorn S, Coyne K, Kelleher C, Hampel C, Artibani W, Abrams P. Population-based survey of urinary incontinence, overactive bladder, and other lower urinary tract symptoms in five countries: results of the EPIC study. Eur Urol 2006;50:13061314.

5. Coyne KS, Sexton CC, Thompson CL, Milsom I, Irwin D, Kopp ZS, Chapple $C R$, Kaplan S, Tubaro A, Aiyer LP, Wein AJ. The prevalence of lower urinary tract symptoms (LUTS) in the USA, the UK and Sweden: results from the Epidemiology of LUTS (EpiLUTS) study. BJU int 2009;104:352-360.

6. Kendirci M, Asci R, Yaman Ö, Çayan S, Orhan I, Usta MF, Ekmekcioglu 0 , Kadioglu A. Prevalence of male pelvic dysfunction: results from the Turkish society of andrology male sexual health study group. Andrology 2014;2:219-224.

7. Abrams $\mathrm{P}$, Artibani W, Cardozo L, Khoury S, Wein A. Clinical manual of incontinence in women. Birmingham, Health Publications, 2005.

8. Shaw C, Tansey R, Jackson C, Hyde C, Allan R. Barriers to help seeking in people with urinary symptoms. Fam pract 2001;18:48-52.

9. Basra R, Artibani W, Cardozo L, Castro-Diaz D, Chapple C, Cortes E, De Ridder D, Pons ME, Haab F, Hohenfellner M, Kirby M, Milsom I, Van Kerrebroeck $P_{1}$ Vierhout $M$, Wagg $A$, Kelleher $C$. Design and validation of a new screening instrument for lower urinary tract dysfunction: the bladder control selfassessment questionnaire (B-SAQ). Eur Urol 2007;52:230-238.

10. Hutchinson A, Bentzen N, König-Zahn C. Cross cultural health outcome assessment: a user's guide: European Research Group on Health Outcomes, 2000.

11. Tarcan T, Mangır N, Özgür MÖ, Akbal C. OAB-V8 Overactive Bladder Questionnaire Validation Study. Bull Urol 2012;21:113-116.

12. Çetinel B, Özkan B, Can G. The Valıdation Study Of ICIQ-SF Turkish Version. Turk J Urol 2004;30:332-338.

13. Sahai $A_{1}$ Dowson $C_{1}$ Cortes $E_{1}$ Seth J, Watkins J, Khan MS, Dasgupta $P_{1}$ Cardozo L, Chapple C, De Ridder D, Wagg A, Kelleher C. Validation of the bladder control self-assessment questionnaire (B-SAO) in men. BJU int 2014;113:783-788.

14. Cidre MJ, López-Fando L, Esteban M, Franco A, Arlandis S, Castro D, Prieto L, Salinas J, Gutiérrez C, Bañosi G, Cambronero J, Grupo de investigación en Resultados de Salud en Urología Funcional y Urodinámica (IFU). How should we address the diagnosis of overactive bladder in women? Actas Urológicas Españolas (English Edition). 2016;40:29-36.

15. Espuña MP, Puig MC, Rebollo PA. Validation of the Spanish version of the "Bladder control Self-Assessment Questionnarie" (B-SAQ). A new screening instrument for lower urinary tract dysfunction. Actas urologicas espanolas. 2006;30:1017-1024.

16. Angulo J, Calderín $M$, Fernández $Y$, González $M$, Gómez $E$, Herreros $M$, Peñasco $P$, Zapatero $M$, Dorado JF. Comparative study of the B-SAO, $\mathrm{OAB}-\mathrm{V} 8$ and $\mathrm{OAB}-\mathrm{V} 3$ questionnaires as screening tools for overactive bladders in clinical practice. Actas Urológicas Españolas (English Edition). 2017:41:383-390.

17. Basra R, Cortes $E$, Khullar V, Kelleher C. A comparison study of two lower urinary tract symptoms screening tools in clinical practice: the B-SAO and OAB-V8 questionnaires. J ObstetGynaecol 2012;32:666-671. 